\title{
BLENDED ONLINE LEARNING: COMBINING THE STRENGTHS OF SYNCHRONOUS AND ASYNCHRONOUS ONLINE LEARNING IN EFL CONTEXT
}

\author{
N. M. W. S. Cahyani'1), N. K. A. Suwastini'2), G. R. Dantes's), I. G. A. S. R. Jayantini(4), I G. \\ A. A. D. Susanthi ${ }^{5}$ \\ 1 English Language Education, Post-Graduate Program, Universitas Pendidikan Ganesha \\ 2 English Language Education, Post-Graduate Program, Universitas Pendidikan Ganesha \\ ${ }^{3}$ Computer Science, Post-Graduate Program, Universitas Pendidikan Ganesha \\ ${ }^{4}$ English Department, Faculty of Foreign Languages, Universitas Mahasaraswati \\ ${ }^{5}$ English Department, Faculty of Letters, Universitas Warmadewa \\ Email:wahyu.suganti@undiksha.ac.id, arie.suwastini@undiksha.ac.id, rasben.dantes@undiksha.ac.id, \\ agung_srijayantini@unmas.ac.id,gungdian03@gmail.com
}

\begin{abstract}
ABSTRAK
Teknologi digital yang multi akses memungkinkan terjadinya pembelajaran daring dengan segala keragaman interaksi guru-siswa, baik dalam moda pembelajaran daring sinkronis maupun dalam moda pembelajaran daring asinkronis. Kajian ini mengulas kembali kekuatan dan kelemahan kedua moda pembelajaran online ini dan mengusulkan perpaduan kedua moda ke dalam model pembelajaran daring campuran dengan memadukan kekuatan kedua moda untuk menutupi kelemahan masing-masing Penelitian ini menggunakan model ulasan literatur oleh Aveyard sebagai metode untuk memahami topik menggunakan data dan argumen dari penelitian-penelitian sebelumnya. 36 artikel digunakan yang terpublikasi di jurnal internasional bereputasi atau terakreditasi nasional pada tahun 2015-2020. Dari ulasan ini, ditemukan pembelajaran daring campuran dengan kombinasi kelebihan-kelebihan dari mode pembelajaran sinkronis dan asinkronis dalam hal aktivitas pembelajaran otentik, fleksibilitas, akses materi, interaksi, pengembangan keterampilan berpikir kritis, pemahaman dan penguasaan materi, dan pembelajaran berfokus pada siswa. Meskipun demikian, tantangan berupa koneksi dan ketersediaan jaringan dari kedua mode pembelajaran masih ditemukan. Hasil kajian ini mengindikasikan bahwa pembelajaran online campuran bisa menjadi penengah yang memfasilitasi pembelajaran daring yang memadukan keuntungan pembelajaran daring sinkronis dan daring asinkronus dengan meminimalkan kelemahan masing-masing moda untuk memberikan pembelajaran daring yang lebih baik bagi siswa.
\end{abstract}

Kata kunci: sinkronis, asinkronis, pembelajaran daring campuran

\begin{abstract}
The ubiquitous use of digital technology brings the inevitability of online learning and its varying degree of teacher-student interactions, both in synchronous and asynchronous online learning modes. This present study reviews the strength and weaknesses of the two online learning modes to propose the use of blended online learning as the combination that harvests the strengths of asynchronous and synchronous modes of online learning with the opportunity to cover each other's weaknesses. The recent study employed Aveyard's literature review model as a method for gaining a comprehensive understanding of a specific topic using data and arguments from previous studies. Thirtysix articles published in reputable international journals or accredited national journals published in 2015-2020 were used. This review revealed that blended online learning combines the strengths of synchronous and synchronous learning in terms of authentic learning activities, flexibility, access, interaction, development of critical thinking, comprehension, and mastery, and student-centered nature of the learning. However, it still retains challenges in terms of network and connection issues from both online learning modes. This finding implies that blended learning can be the middle-ground to facilitate online learning with benefits from both synchronous and asynchronous online modes by minimizing the students' exposure to the weaknesses from the two modes.
\end{abstract}

Keywords : Synchronous, Asynchronous, Blended Online Learning 


\section{INTRODUCTION}

Technology has been developing exponentially [1] and becomes solutions to the world's problems and new challenges for the world to answer [2]. Along with its development, technology also infiltrates learning resulting in an education that seeks for learning achievement combined with digital literacies as means of the 21st Century skills [3], [4], [5], [6], [7], [8], [9], [10], [11], [12]. These shifts lead learners into deep approach learning as means of media information, and communication technology-based have contributed to the education system positively [13] With the support of connectivity, education faced a shift where online learning enables learning despite the time and space [14], [15]. Following this shift, asynchronous and synchronous learning appears as the options for online learning.

Online learning is technology-based learning which has been revolutionizing teaching and learning strategies in such a way that Computer Assisted Language Learning and Mobile Assisted Language Learning are recognized and well-developed in education [17], [14], [15], [18]. Meanwhile, online learning emphasizes the students' needs in clarity of objectives, appropriate rules, techniques, and mechanisms to conduct asynchronous and synchronous online learning. Broadly speaking, there are three main aspects that determine the success of an online learning, namely technologies, teaching strategies, and students' behaviors [16], 19], [20]. Online learning is conducted virtually using online learning platforms that rely on digital devices and internet connections [21], [19], [20], [22]. The use of gadgets such as computers and mobile phones allows online learning to be flexible in terms of access to learning material, from where the students learn, and when the students want to learn [23], [24], [25]. Virtual, Interactive, Real-time, Instructor-led classrooms, and blended using web-cam and audio-enabled devices have proven effective for learning outcomes [26], [20]. Teaching strategies are essential to online learning because they involve planning, instructional designs, and feedback for the students, the target competence, setting for learners' dialogues, and other considerations such as intracultural and intercultural aspects inserted to the instructional designs [27], [22]. Insertion of various sources into the learning designs can promote the use of authentic materials that can expose the students to the target skills more effectively, such as videos, TV series, and newspaper [28], [21]. Students are the center of the learning processes; thus, their attitude and behaviors determine the success of online learning. Online learning allows the students a higher level of autonomy regarding how they learn, when, and doing what activities as directed and supervised by the teachers [28], [29], [30]. [31] specified that motivation and self-regulated learning theory are found in students' participation in collaborative activities, discussion, and responding to the reflective questions, which were perceived positively. They can explore more materials from the internet which the school did not provide, join in homeschooling, continue the study from home or distance learning for those who were dropped out, and help out students who cannot attend face-to-face classroom [23], [32], [33], [22].

Asynchronous Learning refers to online learning involving learners' independence where they do not need to be online simultaneously [26]. While the learning material is posted on the selected platforms such as Learning Management System (LMS) or blogs, the online discussion becomes the primary interaction between the teacher and the students [19]. It becomes the shortcoming of asynchronous learning, where learning only focuses on the discussion forum while isolated learning may bore the students [34], [19], [35]. On the other hand, synchronous learning offers a more real-time online learning experience with direct interaction between the two parties through the use of communication media like chat, application sharing, audio conferencing, and video conferencing [21], [19], [29]. However, synchronous learning seems time-consuming since it tries to replace conventional meetings [19], [35]. [13] and [29] also mention that internet connection is one of the concerning issues in synchronous learning.

Blended Online Learning is then offered as an option that combines the characteristics of the two online learning modes. This learning mode combined conventional classroom and asynchronous and synchronous learning modes [36]. The combination is argued to bring the possibility of tackling the needs for a face-to-face meeting, the connection issues found in synchronous learning, and decreased engagement in asynchronous learning [29]. In other words, the strengths from each mode can be combined so the occurring problems can be reduced. Thus, this study intended to elaborate on the characteristics of online learning, the essential success factors, and the advantages and disadvantages of asynchronous, synchronous, and dan blended Learning. This study also explored further what challenges are faced in the implementation of the online learning modes to provide readers with comprehensive reviews of the strengths and challenges in the implementation of asynchronous and synchronous learning and how some challenges are answered by blended learning while strengths of both synchronous and asynchronous learnings are combined. Such a summary will 
also highlight the challenges posed in blended learning as an invitation for further studies to answer them.

\section{METHOD}

This present study is a literature review where the data source used previous research on the related topic. The study adapted the ten literature review steps from [37] into a qualitative research design. The first step established was deciding a topic to write about and listing research questions. The second step was identifying the literature types used. At this stage, it was decided that the primary sources used would be published research articles and relevant books on the topic. Then, keywords were set on searching for literature in this study, namely "online learning in English learning," "synchronous online learning for improving English," "asynchronous online learning for English classes," "blended learning for English language teaching," "synchronous and asynchronous learning in ELT," and "application of synchronous and asynchronous learning in 21st Century Learning." The fourth step was determining the database from where the articles would be retrieved. Google Scholar was chosen as the database and the application for retrieving the articles. From this process, forty-six articles were selected based on the use of synchronous and asynchronous online learning in English Language Teaching, perception of it, and its role in 21 st-century learning.

The fifth step was doing inclusion and exclusion, limiting those only published in 2015-2020, published in reputable international journals and accredited national journals indexed by Science and Technology Index (SINTA) of National Agency of Research and Education of Indonesia; ranked minimum SINTA 2. With these exclusion/inclusion criteria, thirty-seven articles were selected as data sources, thirty-one of them were published in reputable international journals indexed by Scopus or Web of Science, while the other five were published in accredited national journals, indexed Sinta 1 and Sinta 2. As support to these 36 articles, five books were also cited in the discussion.

After the articles used as data sources were determined, the research commenced to the sixth step, involving the recording of each article by which the researcher used a tabulation table that charts the authors, titles, methods of the study, findings, discussions, and the recommendation of the studies. The seventh step was mapping which articles supported the arguments posed in the present study. It was categorized into synchronous, asynchronous, and blended online learning definitions, characteristics of implementation, success factors, flatforms used, strengths, and challenges faced. The eighth step synthesized information and data into categories that help answer the research questions to similar ideas or data and synthesize them together. In the ninth step, the data was presented in the results and discussion section to answer the research question. The tenth step was drawing a conclusion from the findings and discussion of this study.

\section{FINDINGS AND DISCUSSION}

\section{A. Synchronous Online Learning in EFL Context}

Synchronous Online Learning in the EFL context has been synthesized from 36 articles regarding strengths and weaknesses. In the following section, the findings and discussion will focus on two main parts about Synchronous Online Learning, namely definition-characteristics and strengthsweaknesses.

Synchronous Online Learning deals with live, real-time, and usually scheduled learning, facilitated instruction and interaction, and video conference [33], [38]. It is a set of online learning in a flexible and accessible learning through internet [29], [23], [30], [19], [20], [22]. Synchronous Online Learning can make learning more attractive and interesting because of the affective aspects of the learning, and the emphasis on interpersonal skills activities, teaching presence, social and cognitive presence, feedback from the teacher, motivation and self-regulation, and collaboration [31], [27].

On its implementation, the success of the Synchronous Online Learning mode is affected by several aspects [39], [40], [41]. From those all ten aspects of Online Learning, there are four aspects recognized as the characteristics of Synchronous Online Learning, namely authentic learning activities, flexible learning, live meeting and engaging session, and student-centered nature of learning. These 4 are the most compatible aspects of Synchronous Online Learning, e.g., face-to-face meeting and purposefully used internet [20]. It focuses on flexible online learning platforms, including Zoom Cloud meetings, Virtual Learning environment, Microsoft Teams, and others [30].

Form those all research conducted, the students are assisted in terms of experiences and learning support that can be defined in each benefit and challenge of Synchronous Online Learning 
[13], [41], [23]. In addition, its employment in the EFL context, strengths, and challenges of Synchronous Online Learning is inevitable, summarized below.

Table 4.1. Strengths and Challenges of Synchronous Online Learning

\begin{tabular}{llcc}
\hline No. & Aspects of Online Learning & Strengths & Challenges \\
\hline 1 & Authentic learning activities & $\sqrt{ }$ & \\
2 & A flexible learning & & \\
3 & An accessible learning & $\sqrt{ }$ \\
4 & A Live interactive and engaging session & & \\
5 & Development of critical thinking & & $\sqrt{ }$ \\
6 & Comprehension and topic mastery & $\sqrt{ }$ \\
7 & Enjoyable class & $\sqrt{ }$ \\
8 & Student-centered & $\sqrt{ }$ \\
9 & Connection issues & & $\sqrt{ }$ \\
10 & Network issues & & $\sqrt{ }$ \\
\hline
\end{tabular}

Table 4.1 above shows four strengths of Synchronous Online Learning out of 10 Online Learning aspects. From 36 articles reviewed, those four strengths are found in research on Synchronous Online Learning by 19 researchers. Synchronous Online Learning is beneficial for teachers' authenticity of learning materials [19], [43]. Synchronous Online Learning is argued as a flexible learning [38], [33], [30], [44], [43]. In terms of engagement, Synchronous Online Learning is investigated beneficial for students because of the live meeting and engaging session [38], [33], [30], [44], [43] to prioritize students' independency on their learning or student-centered nature of learning [33], [19], [26], [22]. For instance, [19] investigated speaking in public can be performed through Synchronous Online Learning with the help of a video camera, so the students speak in virtual presence to contribute to the effectiveness of English language learning [31], [23], [33].

Meanwhile, the challenges of Synchronous Online Learning have taken six aspects out of 10 of Online Learning's critical success. From Table 4.1 above, it was listed that challenges are in terms of accessible learning, development of critical thinking, comprehension and topic mastery, enjoyable class, connection issue, and network issue are researched by [38], [45], [22], [13], [46], [47], [48], [49], [40], and [43]. Interaction and feedback in Synchronous Learning seemed not practical, and some students are potentially left out of the meeting and lost in self-learning; they ended up with no comprehension [46]. It was specified that some students get Synchronous Online Learning as a dull moment and excuse to not following the classroom rules [13], [40], [49]. At worst, [46], [13], [45] has investigated that without internet connection, learning will not happen, and opportunities to search and learn will be delayed since they are dependable on one another.

Thus, Synchronous Online Learning has been investigated and reviewed in this study through the function of it by using video and live meeting. Strategical learning to help the students' participation has led this online learning mode into four major strengths that are basically recognized as the key success. Despite successful learning conducted in Synchronous Online Learning; 6 aspects are found as challenges. The challenges are concerned because of the impact on students' learning in the EFL context, such as boredom and difficult access due to connection and network issues.

\section{B. Asynchronous Online Learning in EFL Context}

Asynchronous Online Learning covers mobile devices as supportive tools for discussion. The students mostly rule the main activities themselves, and teachers have to monitor by facilitating their discussion flow. This part will elaborate on the definition, characteristics, strengths, and weaknesses of Asynchronous Online Learning and its strengths and challenges in the EFL Context. 
Asynchronous Online Learning is defined as online learning modes that prioritize discussion chances through readily audio, written, and visual learning materials [38], [40]. It is also learning with internet access which allows class interaction in an online discussion board in 24/7 class [27], [30]. The class taken is based on students' convenience to study and they are all set to work both independently and team-work as collaboration [43], [22]. In its practices in EFL context, Asynchronous Online Learning dominantly covers comments, suggestions, and discussions [49], [15], [33] to foster students' active participation [49], [33].

The success of Asynchronous Online Learning relies on ten aspects of online learning critical success [38], [13], [40], [25], [50]. However, reviews on the articles included in this study revealed five strengths of Asynchronous Online Learning revealed: authentic learning activities, flexible learning, accessible learning, development of critical thinking, and student-centered learning. These strengths confirm the characteristics of Asynchronous Online Learning, which means that these five aspects are crucial to be considered in the implementation. To emphasize, Asynchronous Online Learning prefers offline discussions to live meetings because students seemed to progress better in facilitated discussions [38], [40], [15].

Despite those success factors set and the employment of several trusted platforms, strengths and challenges are observed in the EFL context. From the articles reviewed as data sources, the strengths and challenges of Asynchronous Online Learning are presented in the following table.

Table 4.2. Strengths and Challenges of Asynchronous Online Learning

\begin{tabular}{llcc}
\hline NO & \multicolumn{1}{c}{ Aspects of Online Learning } & Strengths & Challenges \\
\hline 1 & Authentic learning activities & $\sqrt{ }$ & \\
2 & A flexible learning & $\sqrt{ }$ & \\
3 & An accessible learning & & $\sqrt{ }$ \\
4 & A live interactive and engaging session & $\sqrt{ }$ & \\
5 & Development of Critical Thinking & & $\sqrt{ }$ \\
6 & Comprehension and Topic Mastery & & $\sqrt{ }$ \\
7 & Enjoyable Class & $\sqrt{ }$ \\
8 & Student-centered mode & & $\sqrt{ }$ \\
9 & Connection issues & & $\sqrt{ }$ \\
10 & Network issues & & \\
\hline
\end{tabular}

From the table above, the strengths of Asynchronous Online Learning in the EFL context are better at five aspects. Asynchronous Online Learning is investigated beneficial because of the authentic learning activities implied in the EFL context [31], [36], [40], [19]. It has flexible learning system to be accessed as well [38], [13], [23], [41], [20]. [19], [38], [43], [22], [25], [50] argue that Asynchronous Online Learning is accessible. Besides, in improving students' critical thinking development, Asynchronous Online Learning acts importantly [13], [40], [25]. These four aspects related to the 5th aspect, that is the student-centered nature of learning [25], [51], [34], [41], [20], where flexible times and places are proven to raise motivation and social interdependence to deal with cooperation, competition, and individualism and cognitive processes of students [23].

The table above presents data of challenges faced in the implementation of Asynchronous Online Learning. There are 10 out of 36 articles that have been explicitly reviewed in challenges of Asynchronous Online Learning. [34], [47] and [29] investigated that Asynchronous Online Learning is less interactive and engaging, even though the discussion session was conducted in the EFL context. [29] emphasizes that teachers' roles are replaced by technology, and less interaction happens with friends [34]. Then, the comprehension and topic mastery of the students are influenced in this Asynchronous Online Learning [34], [30]. Besides, in terms of class enjoyment, Asynchronous Online Learning is boring, tiring, and less enjoyable [13], [34], [35]. Due to the discussion and downloading 
materials, connection issue is crucial in Asynchronous Online Learning, and network loss is limiting the learning too [47], [49], [20], [51].

To summarize, Asynchronous Online Learning has been introduced to the use of discussion with self-directed activities. It is appropriate to develop critical thinking to raise questions and responses in the discussion constantly.

\section{Blended Online Learning in EFL Context}

The challenges of Synchronous and Asynchronous Online Learning raises the existence of Blended Online Learning as an alternative way for online learning. This part will elaborate definition, characteristics, strengths, and weaknesses of Blended Online Learning as argued by the articles reviewed in this study.

Blended Online Learning is the first online learning which combines Synchronous and Asynchronous Online Learning activities and teaching strategies through the instructional system and learning objectives [16], [42], [36]. It is defined in the way of virtual class deliver the lesson by having presentation posted in Asynchronous Modes or directly presented in Moodle or Virtual meeting [42], [13], [52], [45], [23], [30]. The roles of technology in Blended Online Learning show quality of online learning, sources used, curriculum implemented, and efforts to be literate and be engaged in with the 21st-century learning [34], [41], [20].

From the article's analysis, there are 8 out of 10 aspects that fulfill the success factors of Blended Online Learning. Those are the characteristics of Blended Online Learning in terms of authentic learning used, flexible learning, accessible learning, live interactive and engaging session, development of critical thinking, comprehension and topic mastery, and class enjoyment [46], [52], [30], [13], [39], [15], [29]. Blended Online Learning has not fulfilled the other two aspects, which are connection and network issues. This is because the limitation of access to the internet and different kinds of bandwidth [13], [46], [47], [15], [29], [19], [53]. However, these eight characteristics are profoundly important to be considered in the implementation of Blended Online Learning.

Even though the 36 articles reviewed about Synchronous and Asynchronous Online Learning are blended into Blended Online Learning, strengths and challenges in the EFL context are unavoidable. Those are listed and discussed as follows.

Table 4.3. Strengths and Challenges of Blended Online Learning

\begin{tabular}{llcc}
\hline NO & \multicolumn{1}{c}{ Aspects of Online Learning } & Strengths & Challenges \\
\hline 1 & Authentic learning activities & $\sqrt{ }$ & \\
2 & A flexible learning & $\sqrt{ }$ & \\
3 & An accessible learning & $\sqrt{ }$ & \\
4 & A live interactive and engaging session & $\sqrt{ }$ & \\
5 & The Development of Critical Thinking & $\sqrt{ }$ & \\
6 & Comprehension and topic mastery & $\sqrt{ }$ & $\sqrt{ }$ \\
7 & Enjoyable Class & $\sqrt{ }$ & $\sqrt{ }$ \\
8 & Student-centered & & \\
9 & Connection issues & & \\
\hline
\end{tabular}

From the 36 articles reviewed, 20 of them revealed eight strengths and two challenges of Blended Online Learning. Blended Online Learning is effective in terms of the authentic learning activities involving Zoom, Google Meeting, Whatsapp, E-learning, Google Form, Blog, Youtube, and Instagram in the EFL context [13], [54], [41], [39], [42], [52], [25]. Blended learning has been trusted to carry both Synchronous and Asynchronous Online Learning into flexible choice of teacher [31], [38], [27], [15], [25], [41], [54], [33]. In terms of accessibility to the learning, Blended Online Learning is 
argued giving availability to switch from Synchronous to Asynchronous Online Learning anytime needed [13], [26], [41], [19], [42], [33]. Besides, the live interactive and engaging session belongs to Blended Online Learning's benefit [40], [54], [42], [8]. So then, this leads to the development of students' critical thinking [13], [40]. In Blended Online Learning, the comprehension and topic mastery of the students are also improved [13], [40], [28], [25], [30] focuses on students' feelings, and the result is positively proven that students enjoy the Blended Online Learning. The students are mentioned to be motivated as the center of the learning [25], [52], [55]. However, hindrance in implementing Blended Online Learning are connection issue and network issue come in a chain of technology and internet used [13], [46], [47], [15], [29]; [19], [53]. Specifically, low bandwidth causes slow completion of the study, and the time spent on connection readiness can delay the learning [53]. In this part, the strengths of Synchronous and Asynchronous Online Learning are combined into strengths of Blended Online Learning with additional and correlational strengths as presented in the diagram below.

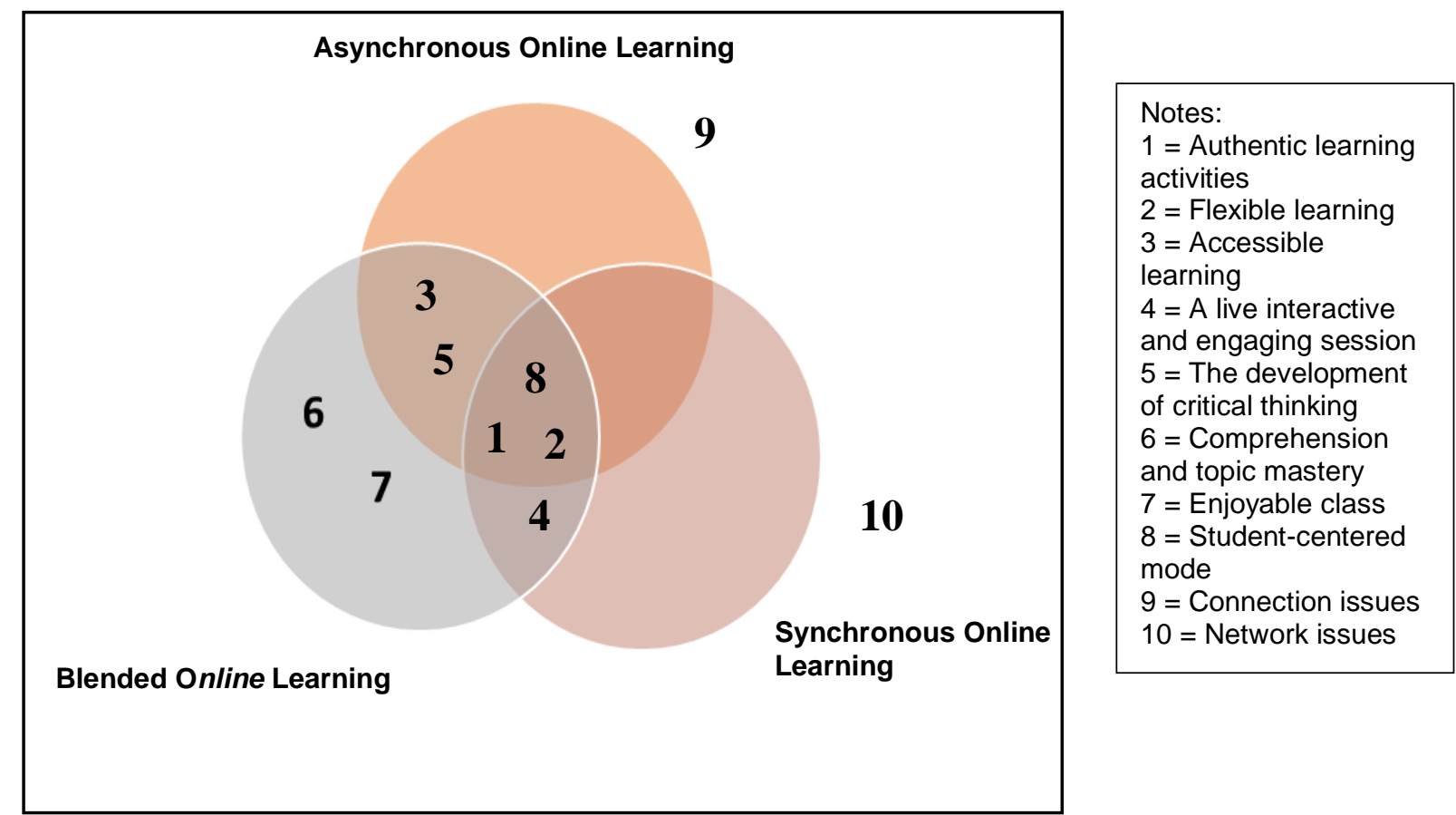

Figure 1. Synchronous, Asynchronous, and Blended Online Learning

The figure 1 above shows four overlapping parts in terms of strengths shared by the three online learning modes. The first overlapping part combines Synchronous, Asynchronous, and Blended Online Learning strengths, shown in numbers 1,2 , and 8 . It means that three of these online learning modes share the same authentic learning activities, flexible learning, and student-centered nature of learning. The second overlapping part in the diagram shows the combination of Asynchronous Online Learning and Blended Online Learning, highlighted in numbers 3 and 5. Asynchronous and Blended Online Learning share the same accessibility in learning and the student's critical thinking. The third is the combination of benefits from Synchronous and Asynchronous Learning in number 4 . It shows an aspect of the live interactive and engaging session in the EFL context. The fourth one is the additional benefit from the Blended Online Learning itself: numbers 6 and 7. The 6 and 7 show comprehension and topic mastery and enjoyable class provided by the Blended Online Learning itself.

Meanwhile, numbers 9 and 10 refer to connection issues and network issues. Both of them are excluded from the strength of the three online learning modes. The educators can help the teaching and learning process to tackle these issues by using the other eight strengths. The teachers can use the flexibility aspect to help themselves in the class conduct by switching the online learning mode whenever connection issues and network issues disrupt the learning. They can switch Synchronous Online Learning into Asynchronous Online Learning by considering good platforms. Since the learning video used and discussion activities require connection, lower bandwidth platforms 
can be used to replace the live meeting or video conference in Synchronous Online Learning. However, authentic learning activities need to be maintained as this is helpful to construct and develop the students' critical thinking and learners' enjoyment.

To conclude, Blended Online Learning covers both Synchronous and Asynchronous Online Learning. Blended Online Learning has benefited both teachers and students in terms of 8 out of 10 aspects of online learning. It is shown in a diagram that Synchronous, Asynchronous, and Blended Online Learning share the same authentic learning activities, flexibility, and the concern of putting students at the center of the learning. Even though those strengths are correlated, connection issues and network issues are still challenging for teachers. However, the challenges can be solved using the flexibility of Synchronous and Asynchronous Online Learning to promote online learning success.

\section{CONCLUSION}

From the reviews conducted on the 36 articles, the present study draws three sets of conclusions. Firstly, Synchronous Online Learning is argued to offer four strengths and six weaknesses when viewed from the ten success factors of online learning. The strengths are in terms of authentic learning activities, flexible learning, live interaction, and student-centered learning process. The weaknesses are in terms of accessibility, development of critical thinking, mastery of topics, enjoyable class, connection issues, and network issues. Secondly, Asynchronous Online Learning is argued to offer five strengths and pose five weaknesses when viewed from the ten success factors of online learning. The strengths cover authentic learning activities, flexible learning, accessibility, development of critical thinking, and student-centered learning. The weaknesses involve lack of interaction, low mastery of content, dull class, connection issues, and network issues. Blended online learning is argued to combine strengths of synchronous and asynchronous online modes with two additional strengths: mastery of content and enjoyable learning process. However, Online Blended Learning still maintains two weaknesses identified in the other two online modes, namely connection issues and network issues.

As blended learning was mentioned to vary the learning and teaching as means of technology strengths toward students' learning performance, it is important to consider this study to be conducted which was supported by previous studies. This suggests the teachers to be manageable in using the technology in the requirements of innovative and positive online learning environments. A suggestion on students' engagement in studying among Synchronous, Asynchronous, and Blended Online Learning also can be conducted as future research references since both can create a positive learning atmosphere.

\section{REFERENCES}

[1] Diamandis, P., \& Kotler, S. (2015). Bold: How to Go Big, Create Wealth, and Impact the World. New York: Simon and Schuster.

[2] Kurzweil, R. A. Y., Branson, S. I. R. R., Ridley, M., Ceo, A. H., \& Pot, H. (2012). Abundance: the future is better than you think. Choice Reviews Online, 49(12), 49-6847-49-6847. https://doi.org/10.5860/choice.49-6847

[3] Trilling, B., \& Fadel, C. (2009). 21st Century Skills - Learning for Life in Our Times -JosseyBass (2009). Journal of Sustainable Development Education and Research, 2(1), 243.

[4] Diamandis, P., \& Kotler, S. (2012). Abundance: The Future Is Better Than You Think. New York: Free Press.

[5] Hutapea, J. V., \& Suwastini, N. K. A. (2019). Using Short Films for Teaching English While Building Characters. Lingua Scientia, 26(1), 33. https://doi.org/10.23887/ls.v26i1.18846

[6] Suwastini, N. K. A., Banjar, I. D. A. O. V. J., Tienty, L. P. C. A., Sasmita, I. M. D. G., \& Nitiasih, P. K. (2020). Rachel Chu as Liberal Feminist in Kevin Kwan' S Crazy Rich Asians (2013). International Journal of Language and Literature, 4(3), 123-132. http://dx.doi.org/10.23887/ijll.v4i3.30297

[7] Diamandis, P., \& Kotler, S. (2020). The Future Is Faster Than You Think: How Converging Technologies Are Transforming Business, Industries, and Our Lives. New York: Simon Schuster. 
[8] Tathahira, T. (2020). Promoting Students' Critical Thinking Through Online Learning in Higher Education: Challenges and Strategies. Englisia: Journal of Language, Education, and Humanities, 8(1), 79. https://doi.org/10.22373/ej.v8i1.6636

[9] Artini, N. N., Suwastini, N. K. A., \& Utami, I. G. A. L. P. (2020). Dory's Paradoxical Characterizations in Disney's Animated Feature Film Finding Dory (2016). NOBEL: Journal of Literature and Language Teaching, 11(1), 27-37. https://doi.org/10.15642/nobel.2020.11.1.27$\underline{37}$

[10] Utami, I. G. A. L. P., Suwastini, N. K. A., Artini, N. N., \& Kultsum, U. (2020). Values of Character Education in the Characterizations of Dory in Disneys' Animated Feature Finding Dory (2016). 394(Icirad 2019), 119-126. https://doi.org/10.2991/assehr.k.200115.020

[11] Puspitasari, P. I., Suwastini, N. K. A., Wisma, G., Ari, K., \& Blangsinga, A. (2021). Boomers ' Perception towards the Implementation of Online Learning amidst Covid-19 Outbreak. 540(Ictes 2020), 128-134.

[12] Ariantini, K. P., Suwastini, N. K. A., Adnyani, N. L. P. S., Dantes, G. R., \& Jayantini, I. G. A. S. R. (2021). Integrating Social Media Into English Language Learning: How And To What Benefits According To Recent Studies. 12(1), 91-111. https://doi.org/10.15642/NOBEL.2021.12.1.91-111

[13] Istifci, I. (2016). Perceptions of Turkish EFL Students on Online Language Learning Platforms and Blended Language Learning. Journal of Education and Learning, 6(1), 113. https://doi.org/10.5539/jel.v6n1p113

[14] Metruk, R. (2019). The call of the MALL: The Use of Smartphones in Higher Education. A literature review. Dilemas Contemporáneos : Educación, Política y Valore; Toluca, 52, 15-16. https://search.proquest.com/openview/08f8cedb19c2df051784db8d28818adc/1 ?pqorigsite $=$ gscholar \&cbl $=4400984$

[15] Firat Altay, I.., \& Altay, A. (2019). A Review of Studies on Blended Learning in EFL Environment conditions of the Creative Commons Attribution license (CC BY-NC-ND). International Journal of Curriculum and Instruction, 11(1), 125-140. https://files.eric.ed.gov/fulltext/EJ1217924.pdf

[16] Yulia, H. (2020). Online Learning to Prevent the Spread of Pandemic Corona Virus in Indonesia. ETERNAL (English Teaching Journal), 11(1), 48-56. https://doi.org/10.26877/eternal.v11i1.6068

[17] Dantes, G. R., Suarni, N. K., Dharsana, I. K., Dantes, N., Jayanta, I. N. L., Suwastini, N. K. A., \& Putra, G. J. A. (2019). Evaluation of e-learning as a learning agent. International Journal of Innovation and Learning, 25(4), 451-464. https://doi.org/10.1504/IJIL.2019.099989

[18] Suarni, N. K., \& Dantes, G. R. (2012). Implementasi Dynamic Intelectual Learning (Dil) Sebagai Salah Satu Adaptive Learning Model. JST (Jurnal Sains Dan Teknologi), 1(1), 19-34. https://doi.org/10.23887/jst-undiksha.v1i1.6020

[19] Rasmitadila, Aliyyah, R. R., Rachmadtullah, R., Samsudin, A., Syaodih, E., Nurtanto, M., \& Tambunan, A. R. S. (2020). The perceptions of primary school teachers of online learning during the covid-19 pandemic period: A case study in Indonesia. Journal of Ethnic and Cultural Studies, 7(2), 90-109. https://doi.org/10.29333/ejecs/388

[20] Martin, F., Stamper, B., \& Flowers, C. (2020). Examining student perception of readiness for online learning: Importance and confidence. Online Learning Journal, 24(2), 38-58. https://doi.org/10.24059/olj.v24i2.2053

[21] Amiti, F. (2020). Synchronous and Asynchronous E-Learning. European Journal of Education and E-Learning Studies, 5(2), 60-70. https://doi.org/10.46827/ejoe.v5i2.3313

[22] Miller, T., \& Edward, P. (2020). Online Learning: Practices, Perceptions, and Technology. Canadian Journal of Learning and Technology. 46(1), 1-27. https://doi.org/10.21432/cilt27894

[23] Padmo, D., Idrus, O., \& Ardiasih, L. S. (2019). The utilization of mobile devices for improving access to online learning for distance Education's Students. Turkish Online Journal of Distance Education, 20(2), 147-161. https://doi.org/10.17718/tojde.557858

[24] Akbarov, A. (2018). 2-18, Akbarov, Azamat, Kemal Gönen, and Hakan Aydogan. Students' Attitudes toward Blended Learning in EFL Context. Acta Didactica Napocensia, 11(1), 61-68. https://doi.org/10.24193/adn.11.1.5.62

[25] Sapti, M. (2019). The Effect of Blended Learning on EFL Students' Grammar Performance and Attitudes: An Investigation of Moodle. Kemampuan Koneksi Matematis (Tinjauan Terhadap Pendekatan Pembelajaran Savi), 53(9), 1689-1699.

[26] Francescucci, A., \& Rohani, L. (2019). Exclusively Synchronous Online (VIRI) Learning: The Impact on Student Performance and Engagement Outcomes. Journal of Marketing Education, 
[27] O'Rourke, B., \& Stickler, U. (2017). Synchronous communication technologies for language learning: Promise \& challenges in research \& pedagogy. Language Learning in Higher Education, 7(1), 1-20. https://doi.org/10.1515/cercles-2017-0009

[28] Tosun, S. (2015). The Effects of Blended Learning on EFL Students' Vocabulary Enhancement. Procedia - Social and Behavioral Sciences, 199, 641-647. https://doi.org/10.1016/i.sbspro.2015.07.592

[29] Wang, N., Chen, J., Tai, M., \& Zhang, J. (2019). Blended Learning for Chinese University EFL learners: Learning Environment and Learner Perceptions. Computer Assisted Language Learning, O(0), 1-27. https://doi.org/10.1080/09588221.2019.1607881

[30] Shukri, A., Nordin, L., Salleh, F. I. M., Raidzwan, S. N. M., \& Ahmad, R. (2020). UniKL students' perception on synchronous learning using ICT as learning tools to learn English. Journal of Critical Reviews, 7(8), 793-796. https://doi.org/10.31838/jcr.07.08.170

[31] Moallem, M. (2015). The Impact Of Synchronous And Asynchronous Communication Tools On Learner Self-Regulation, Social Presence, Immediacy, Intimacy And Satisfaction In Collaborative Online Learning. The Online Journal of Distance Education and E-Learning, 3(3), 53-77. http://tojdel.net/pdf/v03i03/v03i03-08.pdf

[32] Lin, X., \& Li, G. (2020). Students' sense of community and perspectives of taking synchronous and asynchronous online courses. Asian Journal of Distance Education, 15(1), 169-179. http://www.asianjde.org/ojs/index.php/AsianJDE/article/view/448/301

[33] Chen, E., Kaczmarek, K., \& Ohyama, H. (2020). Student perceptions of distance learning strategies during COVID-19. Journal of Dental Education, July, 1-2. https://doi.org/10.1002/jdd.12339

[34] Delahunty, J. (2018). Connecting to learn, learning to connect: Thinking together in asynchronous forum discussion. Linguistics and Education, 46, 12-22. https://doi.org/10.1016/j.linged.2018.05.003

[35] Wijaya, A. N., \& Roki'ah, S. (2020). Critical Thinking Skill Toward Youtube Resources in Students' Argumentative Text. Englisia: Journal of Language, Education, and Humanities, 8(1), 1. https://doi.org/10.22373/ej.v8i1.6622

[36] Karaaslan, H., Kilic, N., Guven-Yalcin, G., \& Gullu, A. (2018). Students' Reflections on Vocabulary Learning through Synchronous and Asynchronous Games and Activities. Turkish Online Journal of Distance Education, July, 53-70. https://doi.org/10.17718/tojde.444640

[37] Aveyard, H. (2010). Doing a Literature Review in Health and Social Care: A Practical Guide. In Social Work Education (Vol. 31, Issue 8). https://doi.org/10.1080/02615479.2012.689493

[38] Shahabadi, M. M., \& Uplane, M. (2015). Synchronous and Asynchronous e-learning Styles and Academic Performance of e-learners. Procedia - Social and Behavioral Sciences, 176(July), 129-138. https://doi.org/10.1016/i.sbspro.2015.01.453

[39] Bataineh, R. F., \& Mayyas, M. B. (2017). The utility of blended learning in EFL reading and grammar: A case for moodle. Teaching English with Technology, 17(3), 35-49. http://www.tewtjournal.org/

[40] Wardani, D. K., Martono, T., Pratomo, L. C., Rusydi, D. S., \& Kusuma, D. H. (2018). Online Learning in Higher Education to Encourage Critical Thinking Skills in the 21st Century. International Journal of Educational Research Review, 146-153. https://doi.org/10.24331/ijere.517973

[41] Potts, J. A. (2019). Profoundly Gifted Students' Perceptions of Virtual Classrooms. Gifted Child Quarterly, 63(1), 58-80. https://doi.org/10.1177/0016986218801075

[42] Sari, I. D. P., \& Rahmah, T. H. (2019). Virtual Discussion for EFL Students Establishing Three Domains: Cognitive, Affective, and Psychomotor. International Journal for Educational and Vocational Studies, 1(3), 249-253. https://doi.org/10.29103/ijevs.v1i3.1586

[43] Francisco, C. D. C., \& Barcelona, M. C. (2020). Effectiveness of an Online Classroom for Flexible Learning. International Journal of Academic Multidisciplinary Research (IJAMR), 4(8), 100-107. https://ssrn.com/abstract=3697055

[44] Yang, J., Yu, H., \& Chen, N. shing. (2019b). Using Blended Synchronous Classroom Approach to Promote Learning Performance in Rural Area. Computers and Education, 141(June), 103619. https://doi.org/10.1016/i.compedu.2019.103619

[45] Yamagata-Lynch, L. C. (2014). Blending online asynchronous and synchronous learning. International Review of Research in Open and Distance Learning, 15(2), 189-212. https://doi.org/10.19173/irrodl.v15i2.1778

[46] Rahardjo, D., Sumardjo, Lubis, D. P., \& Harijati, S. (2016). Internet access and usage in 
improving students' self-directed learning in Indonesia open university. Turkish Online Journal of Distance Education, 17(2), 30-41. https://doi.org/10.17718/tojde.90196

[47] Tsipianitis, D., \& Groumpos, P. (2018). University Asynchronous Distance Learning Programs to Enhance Interregional Sustainable Development. IFAC-PapersOnLine, 51(30), 346-351. https://doi.org/10.1016/j.ifacol.2018.11.329

[48] Weiser, O., Blau, I., \& Eshet-Alkalai, Y. (2018). How do medium naturalness, teachinglearning interactions and Students' personality traits affect participation in synchronous Elearning? In Internet and Higher Education (Vol. 37). Elsevier Inc. https://doi.org/10.1016/j.iheduc.2018.01.001

[49] Peterson, A. T., Beymer, P. N., \& Putnam, R. T. (2018). Synchronous and asynchronous discussions: Effects on cooperation, belonging, and affect. Online Learning Journal, 22(4), 725. https://doi.org/10.24059/olj.v22i4.1517

[50] Lotfi, A. R., \& Pozveh, S. M. H. H. (2019). The Effect of Synchronous and Asynchronous Language Learning: A Study of Iranian EFL Intermediate Students' Vocabulary Learning. Theory and Practice in Language Studies, 9(12), 1585. https://doi.org/10.17507/tpls.0912.16

[51] Zydney, J. M., Warner, Z., \& Angelone, L. (2020). Learning through Experience: Using Design Based Research to Redesign Protocols for Blended Synchronous Learning Environments. Computers and Education, 143(September 2019), 103678. https://doi.org/10.1016/i.compedu.2019.103678

[52] Pardede, P. (2019). Pre-Service EFL Teachers' Perception of Blended Learning. JET (Journal of English Teaching), 5(1), 1. https://doi.org/10.33541/jet.v5i1.955

[53] Karpa, K. (2021). Tips for Converting Interprofessional Education Sessions from In-Person to Remote Synchronous Formats for Experiential Learning. Journal of Interprofessional Education and Practice, 22(October 2020), 100408. https://doi.org/10.1016/..xjep.2020.100408

[54] Yang, J., Yu, H., \& Chen, N. shing. (2019a). Using blended synchronous classroom approach to promote learning performance in rural area. Computers and Education, 141, 103619. https://doi.org/10.1016/i.compedu.2019.103619

[55] Rahiem, M. D. H. (2020). The emergency remote learning experience of university students in Indonesia amidst the COVID-19 crisis. International Journal of Learning, Teaching and Educational Research, 19(6), 1-26. https://doi.org/10.26803/ijlter.19.6.1 